\title{
Current Importance and Potential Use of Low Doses of Gamma Radiation in Forest Species
}

\author{
L. G. Iglesias-Andreu, P. Octavio-Aguilar and J. Bello-Bello \\ Instituto de Biotecnología y Ecología Aplicada, \\ Universidad Veracruzana, Xalapa, Veracruz,
}

México

\section{Introduction}

It is well known that ionizing radiation is currently a very important way to create genetic variability that is not exists in nature or that is not available to the breeder (Ahloowalia \& Maluszynski, 2001; Lemus et al., 2002). Therefore, there are many papers aimed to determine the best radiation dose to applied in plant breeding work. As a result it has been defined intervals gamma radiation useful for many cultivated species, though the determination of the radiosensitivity of tissues by exposure to different intensities of radiation (De la Fe et al., 1996; Castillo et al., 1997; Fuchs et al., 2002; Lemus et al., 2002; Fuentes et al., 2004; Ramírez et al., 2006). However, most studies have been conducted have been designed to evaluate the biological response to high doses of radiation, while in relatively few studies have used low doses to stimulate physiological processes (radiostimulation) although the ionizing radiation hormesis has been widely supported (Luckey, 1980). Hormesis is the excitation, or stimulation, by small doses of any agent in any sistem (Luckey, 2003). The beneficial effect of hormesis has been well documented in species of agricultural importance (Zaka et al., 2004; Kim et al., 2005). However, there is not enough information about its use in forestry. Although little is known about the basic nature of this phenomenon, Vaiserman (2010) had indicated the possible relationship between the hormesis and epigenetic effects. The application of low-dose ionizing radiation could produce in coniferous species hormetics radiostimulants effects through genetic and epigenetic changes that manifest as adaptive responses.

In Mexico and especially in many natural populations of conifers from Veracruz such as Pinus hartwegii Lindl., and Abies religiosa Kunth (Schltdl.) et. Cham., both located in Cofre de Perote, Ver., are seriously affected mainly by the high load of lethal alleles which are causing a serious reduction in reproductive rate and a significant decrease in the production and quality of its seed (Iglesias et al., 2006).

Despite the usefulness of using ionizing radiation to increase the germination potential and generating useful mutations in forestry, there are not many references in the literature on the use of nuclear techniques in these species (Iglesias et al., 2010). Therefore, in this 
chapter will be give a review on the use of low doses of ionizing radiation on forest species, and it will perform a particular consideration to the effect of low doses of gamma radiation on germination and growth of some variables forest species such as $P$. hartwegii and $A$. religiosa.

\section{Uses of low doses of ionizing radiation on plant species}

Ionizing radiation is defined as the energy that propagates in the form of photons (X-rays and $\gamma$ ) or in the form of subatomic particles ( $\alpha, \beta$, neutrons and protons). Among them, gamma rays have been reported to be the most efficient ionizing radiation of creating mutants in plants. Gamma rays belonging to ionizing radiation group are the most energetic form of electromagnetic radiation (Ikram et al., 2010). This kinds of rays possesses the energy level from $10 \mathrm{keV}$ to several hundred kiloelectron volts, and they are considered as the most penetrating physical mutagenic agent in comparison to other radiation source such as alpha and beta rays (Kovács \& Keresztes, 2002). Like other ionining radiation gamma rays interacts with atoms or molecules to produce free radicals in cells. These radicals can induce high mutation in plants because it could produce serious cell damage or afectations in important plant cells components (Kovács \& Keresztes, 2002).

\begin{tabular}{|c|c|c|c|}
\hline Species & $\begin{array}{l}\text { Gamma rays } \\
\text { doses }\end{array}$ & Effects & Reference \\
\hline $\begin{array}{l}\text { Vigna radiata }(\mathrm{L} .) \\
\text { Wilczek. }\end{array}$ & $40-80 \mathrm{kR}$ & Increase polygenic variability. & $\begin{array}{l}\text { Sangwan \& Singh } \\
\text { (1977) }\end{array}$ \\
\hline Triticum aestivum $\mathrm{L}$. & $0.5-7 \mathrm{kR}$ & $\begin{array}{l}\text { Stimulatory effect on height, } \\
\text { tillering and grain yield. }\end{array}$ & Iqbal (1980) \\
\hline Sorghum vulgare L. & $1-10 \mathrm{kR}$ & $\begin{array}{l}\text { Large reduction in mean } \\
\text { seedling height and tillering. }\end{array}$ & Iqbal (1980) \\
\hline Salix nigra Marsh. & $0.1-100 \mathrm{kR}$ & $\begin{array}{l}\text { Low doses increasing the } \\
\text { growth rate. }\end{array}$ & Gehring (1985) \\
\hline Tectona grandis L. f. & $\begin{array}{l}10,20,30,40 \\
\text { and } 50 \mathrm{kR}\end{array}$ & $\begin{array}{l}\text { Improve the germination } \\
\text { rate of the seeds. }\end{array}$ & $\begin{array}{l}\text { Bhargava \& } \\
\text { Khalatkar (1987) }\end{array}$ \\
\hline Allium cepa L. & $\begin{array}{l}10,20,40,80 \\
\text { and } 100 \mathrm{kR}\end{array}$ & $\begin{array}{l}\text { Percentage of abnormal } \\
\text { seedlings increased with } \\
\text { increase in radiation dose. }\end{array}$ & $\begin{array}{l}\text { Amjad \& Akbar } \\
(2003)\end{array}$ \\
\hline Basmati rice varieties & 150 - 300 Gy & $\begin{array}{l}\text { Increase of total spikelets } \\
\text { above the non-irradiated rice. }\end{array}$ & $\begin{array}{l}\text { Ali \& Manzor } \\
\text { (2003) }\end{array}$ \\
\hline $\begin{array}{l}\text { Chrysanthemum } \\
\text { morifolium cv. }\end{array}$ & $\begin{array}{l}15,30 \\
\text { and } 60 \mathrm{~Gy}\end{array}$ & $\begin{array}{l}\text { The regeneration rate decrease } \\
\text { with increase in the total } \\
\text { dose of radiation. }\end{array}$ & $\begin{array}{l}\text { Yamaguchi } \\
\text { et al. (2008) }\end{array}$ \\
\hline Triticum aestivum $\mathrm{L}$. & $\begin{array}{l}10,20,30 \\
\text { and } 40 \mathrm{kR}\end{array}$ & $\begin{array}{l}\text { Irradiated seeds showd } \\
\text { superiority over control } \\
\text { population for several traits. }\end{array}$ & $\begin{array}{l}\text { Singh \& Balyan } \\
\text { (2009) }\end{array}$ \\
\hline Sesamum indicum L. & $\begin{array}{l}200,400,600 \\
\text { and } 800 \mathrm{~Gy}\end{array}$ & $\begin{array}{l}\text { Mutagenic effects by } \\
\text { intergenomic chromosomal } \\
\text { rearrangements. }\end{array}$ & $\begin{array}{l}\text { Kumar \& Singh } \\
(2010)\end{array}$ \\
\hline
\end{tabular}

Table 1. Application of high-doses of ionizing radiation in plant breeding. 
Ionizing radiation can be quantified in terms of absorbed dose (D) which is the amount of ionizing radiation energy deposited per unit mass of irradiated material. Initially, the magnitude was measured in roentgens, called "radiation dose". A Roentgen is a unit of measure used to quantify the radiometric exposure, in other words, the total charge of ions released per unit mass of dry air at standard conditions of pressure and temperature, but now the most often unit used to quantify the biological effects of ionizing radiation is the gray (Gy), which is a unit derived from the international system of units to measure the absorbed dose of ionizing radiation for a certain material. One gray is equivalent to the absorption of one joule of radiation energy per kilogram of irradiated material. Radiation doses are divided into three broad categories:high (> $10 \mathrm{kGy})$, medium (1 to $10 \mathrm{kGy}$ ), and low (<1 kGy).

Gamma rays are widely used for mutation induction in plants. Therefore many studies have been done on the dose-response effects of ionizing radiation, specifically gamma radiation on several growth and yield traits in plants with high-doses of ionizing radiation (Table 1).

\begin{tabular}{|c|c|c|c|}
\hline Species & $\begin{array}{c}\text { Gamma rays } \\
\text { doses }\end{array}$ & Effect & Reference \\
\hline Daucus carota $\mathrm{L}$. & 0.5 and $1 \mathrm{kR}$ & $\begin{array}{l}\text { Irradiation accelerated } \\
\text { germination of carrot seeds. }\end{array}$ & $\begin{array}{l}\text { Bassam \& } \\
\text { Simon (1996) }\end{array}$ \\
\hline Capsicum annuum L. & $\begin{array}{l}2,4,8 \\
\text { and } 16 \mathrm{~Gy}\end{array}$ & $\begin{array}{l}\text { Low doses stimulated the } \\
\text { growth and stress } \\
\text { resistance. }\end{array}$ & Kim et al. (2005) \\
\hline Solanum tuberosum L. & $\begin{array}{l}2.5,5,10 \\
\text { and } 15 \mathrm{~Gy} .\end{array}$ & $\begin{array}{l}\text { Low doses increase the } \\
\text { number of microtubes in } \\
\text { vitro. }\end{array}$ & $\begin{array}{l}\text { Bassam } \\
\text { et al. }(2000)\end{array}$ \\
\hline Beta vulgaris L. & $20 \mathrm{kR}$ & $\begin{array}{l}\text { Induced abnormal floral } \\
\text { structures by mutation. }\end{array}$ & $\begin{array}{l}\text { Chauhan } \\
\text { et al. (2009) }\end{array}$ \\
\hline $\begin{array}{l}\text { Secale montanum } \\
\text { Guss. }\end{array}$ & $\begin{array}{c}0,2,4,6,8,10,12,1 \\
4,16,20,25 \\
\text { and } 30 \mathrm{kR}\end{array}$ & $\begin{array}{l}\text { Increase the frequency of } \\
\text { cells in anaphase and } \\
\text { metaphase. }\end{array}$ & $\begin{array}{l}\text { Akgün \& } \\
\text { Tosun (2004) }\end{array}$ \\
\hline
\end{tabular}

Table 2. Examples of hormetic effects in plants by low doses of ionizing radiation.

Some reports (Gunckel \& Sparrow, 1961; Ikram et al., 2010) have been shown higher exposures of gamma rays produce generally negative effects on plant growth and development although the effect of dose rate on mutation frequency might differs among plant species. These effects include cytological, anatomy, genetical, biochemical, physiological and morphogenetic changes in cells and tissues. Many changes in the plant cellular structure and metabolism e.g., dilation of thylakoid membranes, alteration in photosynthesis, modulation of the antioxidative system and accumulation of phenolic compounds had been documented in different plant species (Kim et al., 2004; Wi et al., 2005). Higher exposures of gamma rays usually produce inhibitor effects on Gymnosperm and Angiosperm seed germination (Kumari \& Singh, 1996) whereas lower exposures produce sometimes a stimulatory effect (Raghava \& Raghava, 1989; Thapa, 1999).

It is important define the threshold between high-doses, in several cases dangerous, and low-doses with stimulatory effects. A radiostimulant low-dose is defined as any doses from 
environmental radiation levels and the threshold that marks the boundary between positive and negative biological effect (Luckey, 2003). This radiostimulatory effects which has been observed in different plant species (Table 2), through the use of low-doses of ionizing gamma radiation could be considered an interesting alternative somewhat unexplored in agriculture and forestry practice.

It has been recognized low-doses of radiation promote increased of cell respiration, enzyme activation, increase in the threshold of lethal doses of radiation, increasing the production of reproductive structures, higher growth, early maturation, accelerated development and disease resistance (Luckey, 1980; 1998). However, most of the works done in this way have been addressed to find the boundaries between hormesis and tissue damage (Castillo et al., 1997; Fuchs et al., 2002; Lemus et al., 2002; Fuentes et al., 2004; Ramírez et al., 2006). There is few researches have been conducted to evaluate the effect of the radiation on the full cycle of the organisms (Cepero et al., 2002; Ramírez et al., 2006). The results obtained in the works of radiostimulation or radiohormesis revealed increases (10-40\%) in agricultural yields, seed germination, contents of carotenes and vitamin $C$ in some vegetables and protein and fat in cereals, finally resistance to diseases and abiotic factors (González et al., 2002; Vasilevski, 2003). On other hand, chronic radiation is another kind of irradiation treatment used to increase variation in different plant species (Sparow \& Woodwell, 1962). This type of irradiation could produce at the plant population level, most severe effects on sexual reproduction because during and after meiosis: (1) nuclear volume is high; (2) chromosome number is reduced after meiosis; (3) the rate of nuclear division may be low, some species requiring two years between meiosis and full maturation of seeds; (4) meiotic pairing and reduction tend to enhance the damage wrought by aberrations which may survive in diploid somatic cells. In forestry was evaluated too the effects of chronic ionizing radiation of low intensity (3-15 r/20 hr day) over a period of several years on the reproductive capacity of the trees, floral abnormalities, as well as growth of their progenies (Mergen \& Stairs, 1962). These authors were found for Pinus rigida a decrease in cone length and in seed germination and seedling height for plants grown from irradiated cones that was associated with an increase in the chronic gamma radiation accumulated by the trees. For Quercus alba was observed visual aberrations in flower morphology in trees receiving from 6 to $12 \mathrm{r}$ /day and a decrease on survival percentage and height growth of seedlings with radiation level (Mergen \& Stairs, 1962). In this case like others mutagenic treatments the relative dosage levels necessary to produce specified responses in growth rate, reproductive capacity or in degree of mortality vary greatly within a species.

Irradiation treatments performed at in vitro culture has been also employed to increase genetic variability and mutants as a potential source of new commercial cultivars (Rasheed et al., 2003; Orbovic' et al., 2008). So, tissue culture techniques offer a wide choice of explants (initial plant material) for gamma radiation treatment (cells, tissues, somatic embryos and organs). These explants will give origin to complete plants composed of a few or even of one cell with a higher probability for find mutated cells. In vitro culture also allows for the handling of unlimited vegetative material for radiation treatment, aseptic and controlled in vitro selection, and micropropagation of selected variants (so called somaclones). In addition, according to Predieri (2001), tissue culture increases the efficiency of mutagenic treatments for variation induction, handling of large populations, use of ready selection methods, and rapid cloning of selected variants. 
Recent developments in biotechnology-especially in understanding the structure and function of plant genomes - confirms in vitro mutation induction as one of the most efficient and cost-effective tools for functional genomics projects dealing with both forward and reverse genetics strategies (Jain, 2001; Shu \& Lagoda, 2007). The high number of research reports suggests also that mutagenesis in combination with tissue culture has high potential in plant breeding programs. It has been indicated (Maluszynski et al., 1995), that the use of tissue culture techniques can overcome some of the limitations in the application of mutation techniques; these are the lack of effective mutant screening techniques and the unrealistically large but necessary size of the mutated population, calculated on the basis of an expected mutation frequency for a desired trait. The determination of radio-sensitivity tests, irradiation with optimal doses and multiplication of irradiated material through in vitro mutation techniques has assumed a new dimension (Ahloowalia \& Maluszynski, 2001). An example of setting the boundary between and tissue damage from ionizing radiation was shown by Fuchs et al. (2002). These authors found in callus culture of Saccharum sp. (sugarcane), dose of greater than $4 \mathrm{kR}$ of gamma radiation eliminated any possibility to induce an organogenetic process in this tissue. In this case, the hormetic threshold (2 to $4 \mathrm{kR}$ ) was much lower that applied to seeds of other species (4 to $20 \mathrm{kR}$ ) (Lemus et al., 2002; Ramírez-Calderón et al., 2003; González et al., 2004).

\section{Hormesis and molecular mechanisms of the adaptive response}

The hormesis term comes from greek meaning "to excite". Exposure of sublethal doses of ionizing radiation can induce protective mechanisms against a subsequent higher dose irradiation. So, the hormesis is the excitement and stimulation by small doses of any agent on any system. Luckey (1980), in his book entitled "Hormesis", documented thousand experiments where fungi and other lower life forms were seen to prosper with doses of radiation exceeding their normal background exposures with ionizing radiation. In a second book entitled "Radiation Hormesis" (Luckey, 1991) examined hundreds of studies on animals and humans, showing that low levels of radiation were beneficial to health, longevity, and reproduction.

Many studies have been also indicated that pre-expose to low dose radiation (or some other genotoxic agent) can change radiosensitivity, reducing score of chromosomal aberrations, micronuclei and mutations. This phenomenon is called adaptation and could be related with defense mechanisms some of them have evolved to minimize genotoxic damage. One of these is induced radioresistance or adaptive response (AR). The term "adaptive response" usually means that a relatively small "conditioning" radiation dose induces increased radioresistance when the cells are irradiated with higher doses several hours later (Hillova \& Drasil, 1967). Thus, radioadaptive response induction expresses the ability of low dose radiation to induce cellular changes that alter the level of subsequent radiation-induced or spontaneous damage (Amundson et al., 1999). The exposure to minimal stress inducing a very low level of damage can trigger an AR resulting in increased resistance to higher levels of the same or of other types of stress (Patra et al., 2003; Asad et al., 2004; Girigoswami \& Ghosh, 2005; Yan et al., 2006). The AR could be considered a nonspecific phenomenon and have been confirmed but not explained by many studies. Adaptation after preexposure to chronic or prolonged exposure to low-level radiation doses was not often described. 
Several types of cellular responses to ionizing radiation, such as the adaptive response, suggest that low-dose radiation may possess characteristics that distinguish it from its highdose counterpart. Accumulated evidence also implies that the biological effects of low-doses and high-doses of ionizing radiation are not linearly distributed. This is an important physiological effect of exposure to low doses of radiation. The radioadaptive was first documented in a convincing way to protect against chromosomal aberrations (Scott et al., 2009).

The capability of forest tree species to adapt to the new environments not only will depend on their genetic background, but also rely on their phenotypic plasticity. Several reports have shown the involvement of epigenetic modifiers as the basis of the phenotypic plasticity, and in particular to the adaptation to abiotic stresses. DNA methylation is one the most important epigenetic modification in eukaryotes. It is involved in specific biological processes such as gene transcription regulation, gene silencing, mobile element control or genome imprinting. Therefore, there is a great interest in analyzing methylation levels and distribution within the genome. Epigenetic regulation of gene activity is widespread in the genome of eukaryotic cells and can lead to silencing or activation of gene expression. According to Scott et al. (2009), high doses of radiation can promote epigenetically silencing of adaptive response genes, for example via promoter associated DAN and /or histone methylation or deacetylation.

Adaptive-response genes can be stabilized and activated in response to cellular stress (e.g., low dose radiation) through post translational modifications that include acetylation (Ito et al., 2002). This radiation, above a stochastic threshold stimulate intracellular and intercellular signaling that leads to activated natural protection (ANP) against cancer and other genomic-instability-associated diseases (Scott, 2005; Scott \& Di Palma, 2006).

The AR has been observed in bacteria (Assis et al., 2002; Sedgwick \& Lindahl, 2002; Rohankhedkar et al., 2006), yeast (Boreham \& Mitchel, 1991; Gajendiran \& Jeevanram, 2002), algae (Chankova \& Bryant, 2001; Rubinelli et al., 2002; Chankova et al., 2007), insect cells (Savina et al., 2003), mammalian cells (Wang \& Cai, 2000; Tiku \& Kale, 2001; Ulsh et al., 2004; Zhou et al., 2004), human cells (Schlade-Bartusiak et al., 2002; Atanasova et al., 2005; Coleman et al., 2005; Friesner et al., 2005; Lanza et al., 2005; Seo et al., 2006) and higher plants models (Rieger et al., 1993; Panda et al., 1997; Jovtchev \& Stergios, 2003; Patra et al., 2003). A study of the conditions essential for the induction of an adaptive response is of critical importance to understanding the novel biological defense mechanisms against the hazardous effects of radiation. The results statistically significant with microorganisms, plants, non vertebrates and other animals of experimentation, showed the existence of a radiogenic metabolism, in other words, a metabolism promoted by ionizing radiation.

Little is currently known about the precise mechanisms of AR. There is evidence that different stress conditions can activate similar defense mechanisms in biological systems (Joiner et al., 1996; 1999; Babu et al., 2003). The AR probably involves the transcription of many genes and the activation of numerous signaling pathways that trigger cell defenses more efficient detoxification of free radicals, DNA repair systems, induction of new proteins in irradiated cells with a conditioning dose, and enhanced antioxidant production (Wolff, 1998; Mendez-Alvarez et al., 1999; Pajovic et al., 2001; Assis et al., 2002; Chankova \& Bryant, 2001; Coleman et al., 2005; Lanza et al., 2005). There is evidence that 
DNA repair underlies the AR induced by low radiation doses in human and plant cells (Lambin et al, 1994; Patra et al., 2003) by increasing the amount and rate of DNA repair (Joiner et al., 1996; 1999). It has been proposed that these effects could be related to the induction of an AR. A clue as to the nature of the underlying process was provided by results showing a dependence on de novo protein synthesis. The synthesis of DNAbinding proteins (MWs 50, 74 and $130 \mathrm{kdal}$ ) was found in radiation-conditioned cells of $C$. reinhardtii (Bryant, 1979). The induction of new protein synthesis by low doses could be caused by an effect of low doses on chromatin conformation near genes coding for DNA repair proteins (Belyaev et al., 1996). For example, there are earlier observations that hydrogen peroxide induced a cross-adaptive response to cumene hydroperoxide in $E$. coli which did not require novel gene products but involved modification of the small subunit of Ahp, a protein involved in the protection against alkyl hydroperoxides (Asad et al., 1998). On the other hand, Reactive Oxygen Species (ROS) could serve as signal transducers in plant and animal cells (Babu et al., 2003; Matsumoto et al., 2004). As signaling molecules, ROS might affect the development of AR through participation in the damage-sensing process after conditioning dose exposure.

\section{Current and potential use of low ionizing radiation in forestry: A case study}

At present there are virtually no studies of hormesis by ionizing radiation in forest species. Most of the work focused radiation treatment of species of agronomic interest since they have shorter lifetime and germination time, the tissues of this type of seeds have a greater amount of water, which maximizes the effect of radiation; and the generation of seedlings is much easier in the herbaceous form.

One of the few jobs that exist in tree species was conducted with Araucaria angustifollia (Bert) O. Kuntze (Ferreira et al., 1980). The study showed a hormetic effect on seed germination and seedling growth at low doses of gamma radiation ( 0.1 to $0.4 \mathrm{kR})$. This first study showed the effectiveness of ionizing radiation to improve seed germination in species of trees, one of the main agronomic traits for forest management.

Abies religiosa (fir) and Pinus hartwegii are two conifer species that develop on the National Park Cofre de Perote, Veracruz, Mexico. Both have great ecological ( $P$. harwegii is the conifer species taking place at higher altitudes) and economical importance (in particular, the fir is valuable for its timber, trementine production and as an ornamental Christmas trees). These forests have protective functions to other resources to cushion the effects of environmental pollution and contribute as a regulation of the hydrological cycle (Solís, 1994).

In Veracruz, these populations develop principally in the National Park Cofre de Perote and Pico de Orizaba between 2800 y 3500 m.a.s.l. in $17^{\circ} 30^{\prime}$ to $20^{\circ} 00^{\prime} \mathrm{N}$ and $97^{\circ} 104^{\prime} \mathrm{W}$ (Manzanilla 1974; Sánchez-Velásquez \& Pineda-López 1993). Both species have been seriously affected by fire and logging clandestine, has resulted in a reduction of the effective size of the same low viability and high percentage of abortive seeds, and a significant decrease in reproductive rate, apparently due to manifestation of the phenomenon of inbreeding depression, common in coniferous species (Williams \& Savolaienen, 1996). But, in both species, is common a low reproductive rate (Franklin, 1974). 
Despite the potential utility of the low doses of ionizing radiation for the induction of hormetic effects in these species, to date have not implemented these techniques to increase the germination potential and generating useful mutation in forestry. Therefore, we study the mutagenic effect of gamma radiation and know whether low doses of radiation can have a stimulatory effect on germination and development of $P$. hartwegii and A. religiosa. Twenty-five to thirty cones of $A$. religiosa and $P$. hartwegii were collected in populations that develop on 3510 m.a.s.l., in the locality "El Conejo", both located in the National Park "Cofre de Perote" Veracruz, Mexico. These populations are fragmented and have been affected by significant changes in land use to agricultural crops (Sánchez-Velásquez et al., 1991).

To apply the mutagenic treatments, seeds were extracted from the cones collected, and kept under controlled conditions at a relative humidity of $8 \%$. Two replicates of 100 seeds of each species at low doses $(2,5,10,15$ and $20 \mathrm{~Gy})$ of gamma radiation $\left(\mathrm{Co}^{60}\right)$ were made. The seeds for irradiation were placed at a distance of $80 \mathrm{~cm}$ (for a field of $30 \times 30 \mathrm{~cm}$ ), with the help of a head of the Cobalt 60 Unit (Theraton 780e) in the "Centro de Cancerologia de Xalapa, Veracruz, Mexico; and plastic tray, which was secured in a cage at $50 \mathrm{~cm}$ from the radiation source (Figure 1). Subsequently, the irradiated seeds of each species and their corresponding controls were planted separately under greenhouse conditions in trays containing a mixture of forest soil and sand in a 1:1 ratio. In both cases we used a randomized complete block design with three replications. Seedlings were transferred to plastic bags for study.

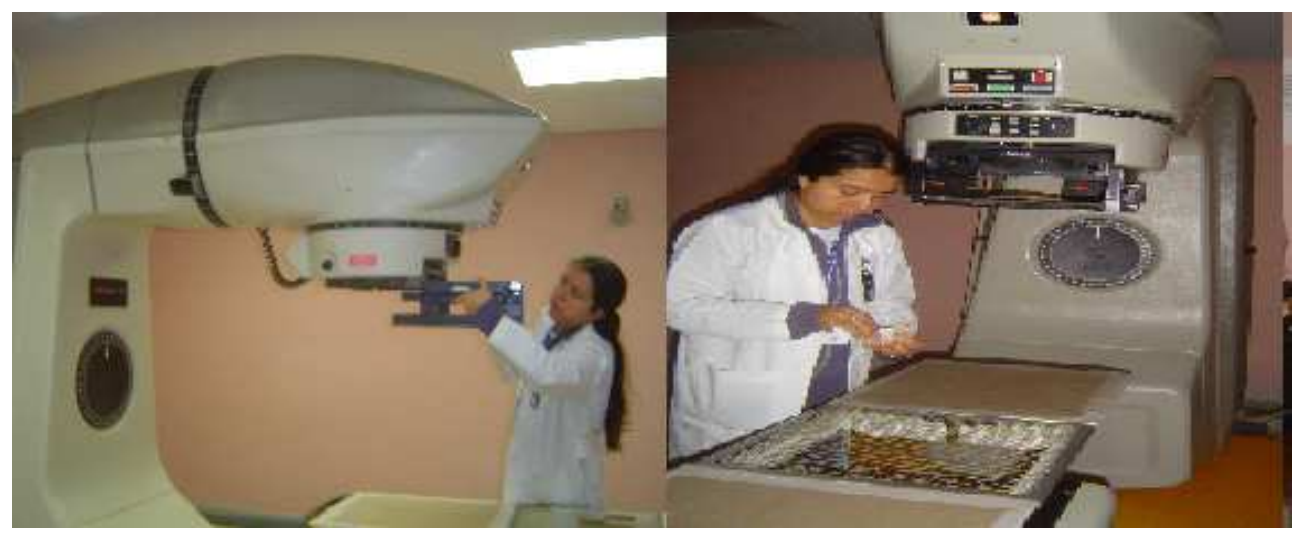

Fig. 1. Cobalt 60 Unit (Theraton 780e), used for irradiation of seeds of Abies religiosa and Pinus hartwegii, located in Centro Estatal de Cancerología de Xalapa, Veracruz, Mex.

To evaluate the effect of the applied radiation dose was counted the number of seeds germinated at 90 days for each dose studied; the percentage of germination was calculated. Was considered germinated seeds showed a greater than $5 \mathrm{~mm}$ radical length. At 45 days, was evaluated the height and number of needles of each seedling. Height $(\mathrm{cm})$ was measured with a millimeter rule from the base of the stem of the root to the terminal bud. From the measurements we calculated the percentages of germination, plant height and number of needles as a relative value with respect to control.

The results showed a significant radiostimulating effect on the germination of the seeds of Abies religiosa and Pinus hartwegii treated with low doses of gamma radiation (Figure 2). 


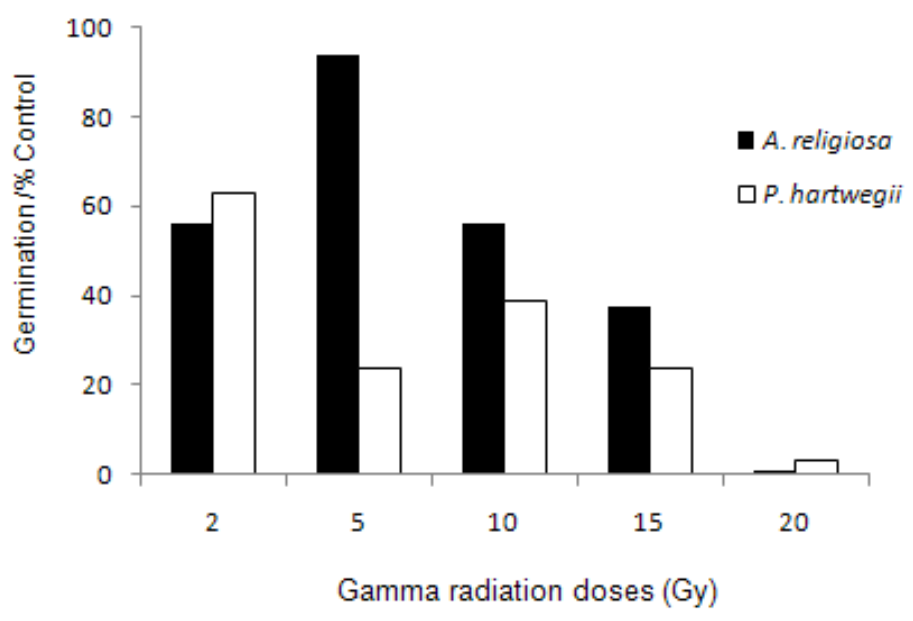

Fig. 2. Effect of the gamma radiation on seed germination in Abies religiosa and Pinus hartwegii.

According to these results the radiostimulatory effect was more pronounced in Pinus hartwegii since treatment of 2 Gy resulted in a high percentage of germination. 5 Gy dose was most effective to induce a similar effect on the fir.

These results are consistent with the radiostimulatory effect observed by Rudolph (1979) and Sokolov et al. (1998) to evaluate the germination of seeds of Pinus bankasiana and P. sylvestris, respectively. On the other hand, showed that, like as detected by Nwachukwu et al. (1994) and Lemus et al. (2002); the frequency of mutation increased with the percentages of germination. The few seedlings that managed to germinate at the highest doses of gamma radiation showed thickened short roots and therefore were less vigorous and did not survive.

Low doses of gamma radiation used in both species showed similar radiostimulatory effects on the characters of the seedling height and number of needles (Figure $3 a, b$ ).
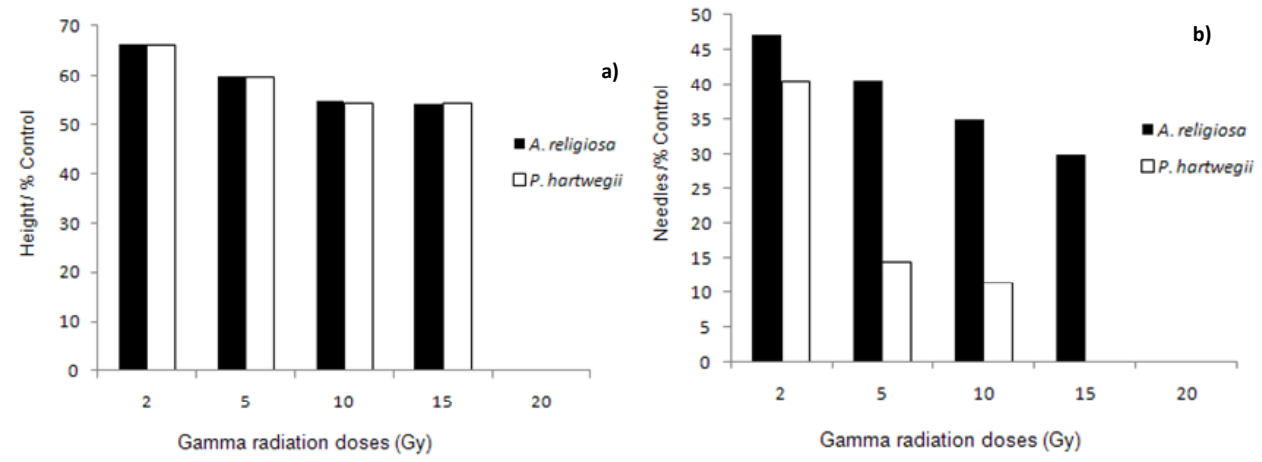

Fig. 3. Effect of the low-doses of gamma radiation on height (a) and number of needles in seedlings (b), in Pinus hartwegii and Abies religiosa. 
As for the variable germination, was found at 2 Gy a radiostimulatory effect on height and number of needles of the seedlings of $P$. hartwegii. In fir, this effect is slightly higher.

In addition, there was a trend towards reduction in height and number of needles in both species as they increased the dose of radiation. This effect was more pronounced for the number of needles of $P$. hartwegii (Figure $3 \mathrm{~b}$ ).

According to Olvera \& West(1985); reducing the growth of seedlings generated from seeds treated with high doses of radiation is mainly due to the destruction of auxin and its precursors. It should be noted that the height variable is used in this type of study as the most sensitive indicator of radiation.

Based on our results consider the possibility of using the aforementioned dose to induce mutations that may be of interest in these species. However, all the applied doses produced a negative effect on the number of needles per plant, which are fundamental in the production of Christmas trees. Doses of 2, 5 and 10 Gy gave average values ranging from 3.3 to 6.8 needles per seedlings, well below the average control value, which was 27.7 in $P$. hartwegii. Contravention in the production because mutations are required to encourage a more fodder for a demanding market of this product.

It has been suggested in this regard that high doses of radiation cause damage that affects physiological character related to growth, especially with the number of needles. High doses of radiation can alter in a direct or indirect the DNA, causing damage of bases, single strand breaks and chromosomal alterations, serious and irreversible destruction of the membrane system of mitochondria and chloroplasts (Ladanova, 1993). However, it will take more repetitions to achieve seedlings with large needles and branches, or select for traditional breeding seedlings with large needles for future generations.

In summary, prolonged exposure to radiation by gamma rays produced a severe effect on almost all variables; this effect was greater in the seeds irradiated with 15 and $20 \mathrm{~Gy}$. In the range of medium dose (5 Gy), radiation induced lesions can eventually lead to an important radiobiological response, which at the cellular level can alter the viability and even cause cell death (Ward, 1988).

This response was manifested by affectations in traits related to germination and seedling growth, as the germination percentage and number of needles that were most affected. On the other hand, not all variables were impacted in the same direction, since a dose of $5 \mathrm{~Gy}$ showed the presence of a radiopositive effect in the percentage of germination for fir, and at doses of 5 - 10 Gy there was a negative effect at the height of the plant and number of needles, with respect to control. However, when analyzing these results it is recommended to fully explore dose of 5 Gy for A. religiosa, and other below 2 Gy for P. hartwegii, in accordance with the sensitivity shown by this species to gamma radiation for improve the germination rate.

\section{Conclusions}

With all these examples we can say that low doses of ionizing radiation could improve the crop by increasing production, reducing the time of germination, accelerate growth of seedlings and generate interest new varieties of some plant species, including trees. 
However, to achieve these results it is important to set the threshold hormetic species specific depending upon the type of tissue that is irradiated, the quantity of humidity inside the tissue and establish an appropriate model depending on the type of production that is required.

Radiation hormesis provides the basis for appropriate utilization of ionizing radiation as a useful tool in our society. It can provide more efficient use of resources, maximum production of grain, vegetables, and meat, and increased health and longevity. Efficient utilization of nature's resources demands support to explore the practical application of radiation hormesis.

\section{References}

Ahloowalia, B. \& Maluszynski, M. (2001). Induced mutations- A new paradigm in plant breeding. Euphytica, 118(2):167-173.

Akgün, I. \& Tosun, M. (2004). Agricultural and Cytological Characteristics of M1 Perennial Rye (Secale montanum Guss.) as effected by the application of different doses of Gamma Rays. Pakistan Journal of Biological Science, 7(5):827-833.

Ali, C. \& Manzoor, A. (2003). Radiosensitivity studies in basmati rice. Pakistan Journal of Botany, 35(2):197-207.

Amjad, M. \& Akbar, A. (2003). Effect of post-irradiation storage on the radiation-induced damage in onion seeds. Asian Journal of Plant Science, 2(9):702-707.

Amundson, S.; Do, K. \& Fornace, A. (1999). Induction of stress genes by low doses of gamma rays. Radiation Research, 152:225-231.

Asad, N.; Asad, L.; Silva, A.; Felzenszwalb, I. \& Leitão, A. (1998). Hydrogen peroxide induces protection against lethal effects of cumene hydroperoxide in Escherichia coli cells: An Ahp dependent and OxyR independent system? Mutants Research 407:253259.

Asad, N.; Asad, L.; De Almeida, C.; Felzenszwalb, I.; Cabral-Neto, J. \& Leitão, A. (2004). Several pathways of hydrogen peroxide action that damage the E. coli genome. Genetic and Molecular Biology, 27:291-303.

Assis, M.; De Mattos, J.; Caceres, M.; Dantas, F.; Asad, L.; Asad, N.; Bezerra, R.; Caldeira-deAraujo, A. \& Bernardo-Filho, M. (2002). Adaptive response to $\mathrm{H}_{2} \mathrm{O}_{2}$ protects against $\mathrm{SnCl}_{2}$ damage: The OxyR system involvement. Biochemistry, 84:291-294.

Atanasova, P.; Hadjidekova, V. \& Darroudi, F. (2005). Influence of conditioning on cell survival and initial chromosome damage in X-irradiated human cells. Trakia Journal of Science, 3:37-42.

Babu, S.; Akhtar, T.; Lampi, M.; Tripuranthakam, S.; Dixon, G. \& Greenberg, B. (2003). Similar stress responses are elicited by copper and ultraviolet radiation in the aquatic plant Lemna gibba: Implication of reactive oxygen species as common signals. Plant Cell Physiology, 44:1320-1329.

Bassam, A. \& Simon, P. (1996). Gamma irradiation-induced variation in carrots (Daucus carota L.). American Society for Horticultural Science, 121(4): 599-603. 
Bassam, A.; Ayyoubi, Z. \& Jawdat, D. (2000) The effect of gamma irradiation on potato microtuber production in vitro. Plant Cell, Tissue and Organ Culture, 10.1023/ A:1006477224536.

Belyaev, I.; Spivak, I.; Kolman, A. \& Harms-Ringdahl, M. (1996). Relationship between radiation induced adaptive response in human fibroblasts and changes in chromatin conformation. Mutant Research, 358:223-230.

Bhargava, Y. \& Khalatkar, A. (2004). Improve performance of Tectona grandis seeds with gamma irradiation. Acta Horticulturae, 215:51-54.

Boreham, D. \& Mitchel, R. (1991). DNA lesions that signal the induction of radioresistance and DNA repair in yeast. Radiation Research, 128:19-28.

Bryant, P. (1979). Evidence for inducible DNA-associated proteins formed during the development of increased resistance to radiation in Chlamydomonas. Progress Physic and Theoretical Chemistry, 6:305-313.

Castillo, J.; Estévez, A.; González, M.; Castillo, E. \& Romero, M. (1997) Radiosensibilidad de dos variedades de papa a los rayos gamma de 60Co. Cultivos Tropicales, 18(1): 62-65.

Cepero, L.; Mesa, A.; García, M. \& Suárez, J. (2002). Efecto de la radiación láser en semillas de Albizia lebbeck. I. fase de vivero. Pastos y Forrajes. 25 (3):181.

Chankova, S. \& Bryant, P. (2001). Acceleration of DNA-double strand rejoining during the adaptive response of Chlamydomonas reinhardtii. Radiation Biology and Radioecology, 42(6):600-603.

Chankova, S.; Dimova, E.; Dimitrova, M. \& Bryant, P. (2007). Induction of DNA doublestrand breaks by zeocin in Chlamydomonas reinhardtii and the role of increased DNA double-strand breaks rejoining in the formation of an adaptive response. Radiation and Environmental Biophysics, 46:409-416.

Chauhan, S.; Nakashima, H. \& Kinoshita, T. (2009). Gamma-ray induced abnormal floral mutants in sugar beet (Beta vulgaris L.) The International Journal of Plant Reproductive Biology, 1(2):137-140.

Coleman, M.; Yin, E.; Peterson, L.; Nelson, D.; Sorensen, K.; Tuckera, J. \& Wyrobeka, A. (2005). Low-dose irradiation alters the transcript profiles of human lymphoblastoid cells including genes associated with cytogenetic radioadaptive response. Radiation Research, 164:369-382.

De la Fe, C.; Romero, M. \& Castillo, E. (1996). Radiosensibilidad de semillas de papa a los rayos gamma 60Co. Cultivos Tropicales, $17(3):$ 77-80.

Ferreira, C.; Do Nascimento, V.; Ferreira, M. \& Vencovscky, R. (1980). Efeito de baixas doses de radiacao fama na conservacao do poder germinativo de sementes de Araucaria angustifolia (Bert) O. Kuntze. IPEF, 21:67-82.

Franklin, F. (1974). Abies Mill. (Fir) Gen. Tech. rep W/N. USDA. Forest Service Pacific Northwest Forest and Range Experiment Station. USA.

Friesner, J.; Liu, B.; Culligan, K. \& Britt, A. (2005). Ionizing radiation- dependent $\gamma-H 2 A X$ focus formation requires ataxia telangiectasia mutated and ataxia telangiectasia mutated and Rad3-related. Molecular Cell Biology, 16:2566-2576.

Fuchs, M.; González, V.; Castroni, S.; Díaz, E. \& Castro, L. (2002). Efecto de la radiación gamma sobre la diferenciación de plantas de caña de azúcar a partir de callos. Agronomía Tropical, 52:311-323. 
Fuentes, J.; Santiago, L.; Valdés, Y.; Guerra, M.; Ramírez, I.; Prieto, E.; Rodríguez, N. \& Velázquez, B. (2004). Mutation induction in zygotic embryos of avocado (Persea americana Mill). Biotecnología Aplicada, 21:82-84.

Gajendiran, N. \& Jeevanram, R. (2002). Environmental radiation as the conditioning factor for the survival of yeast Saccharomyces cerevisiae. Indian Journal of Experimental Biology, 40:95-100.

Gehring, R. (1985). The effect of gamma radiation on Salix nigra Marsh. Cuttings. Arkansas Academy of Science Proceedings, 39:40-43.

Girigoswami, B. \& Ghosh, R. (2005). Response to gammairradiation in V79 cells conditioned by repeated treatment with low doses of hydrogen peroxide. Radiation Environmental Biophysics, 44:131-137.

González, L.; Ramírez, R. \& Camejo, Y. (2002). Estimulación del crecimiento y desarrollo de plántulas de tomate del cultivar Santa Clara a los rayos gamma del 60Co. Alimentaria, 331: 67-70.

González, G.; Alemán, S.; Barredo, F.; Keb, M.; Ortiz, R.; Abreu, E. \& Robert, M. (2004). Una alternativa de la recuperación henequenera de Cuba, mediante el uso de técnicas biotecnológicas y moleculares. Biotecnología Aplicada, 21 (1): 44-49.

Gunckel, J. \& Sparrow, A. (1961). Ionizing radiation: Biochemical, Physiological and Morphological aspects of their effects on plants. In: Encyclopedia of Plant Physiology, Ruhland,W. pp. 555-611, Springer-Verlag, Berlin.

Hillova, J. \& Drasil, V. (1967). The inhibitory effect of iodoacetamide on recovery from sublethal damage in Chlemydomonas reinbardi. International Journal of Radical Biology, 12:201-208.

Iglesias, L.; Mora, I.; Casas, J. (2006) Morfometría, viabilidad y variabilidad de las semillas de la población de Pinus hartwegii del Cofre de Perote, Veracruz, México. Cuadernos de Biodiversidad, 19:14-22.

Iglesias, L.; Sánchez-Velásquez, L.; Tivo-Fernández, Y.; Luna-Rodríguez.; Flores-Estévez, N.; Noa-Carrazana, J.; Ruiz-Bello, C. \& Moreno-Martínez, J. (2010). Efecto de radiaciones gamma en Abies religiosa (Kunth) Schltd. (et Cham). Revista Chapingo. Serie Ciencias Forestales y del Ambiente, 16(1): 5-12.

Ikram, N.; Dawar, S.; Abbas, Z. \& Javed, Z. (2010). Effect of (60cobalt) gamma rays on growth and root rot diseases in mungbean (Vigna radiata 1.). Pakistan Journal of Botany, 42(3):2165-2170.

Iqbal, J. (1980). Effects of acute gamma irradiation, developmental stages and cultivar differences on growth and yiel of wheat and sorghum plants. Environmental and Experimental Botany, 20(3):219-231.

Ito, D.; Walker, J.; Thompson, C.; Moroz, I.; Lin, W. \& Veselits, M. (2004). Characterization of stanniocalcin 2, a novel target of the mammalian unfolded protein response with cytoprotective properties. Molecular Cell Biology, 24:9456-69.

Jain, S. (2001). Tissue culture-derived variation in crop improvement. Euphytica, 118:153-166.

Joiner, M.; Lambin, P.; Malaise, E.; Robson, T.; Arrand, J.; Skov, K. \& Marples, B. (1996). Hypersensitivity to very-low single radiation doses: Its relationship to the adaptive response and induced radioresistance. Mutation Research, 358:171-183. 
Joiner, M.; Lambin, P. \& Marples, B. (1999). Adaptive response and induced resistance. Critical Academic Science, 322:167-75.

Jovtchev, G. \& Stergios, M. (2003). Genotoxic and adaptive effect of cadmium chloride in Hordeum vulgare meristem cells. Comptes Rendus Academic Bulgarian Science, 56:7580.

Khalatkar, A. \& Bhargava Y. (1987) Effect of gamma radiations on the nuts (Seeds) of Anacardium occidentale. ISHS Acta Horticulturae, 215:45-50.

Kim, J.; Baek, M.; Chung, B.; Wi, S. \& Kim, J. (2004). Alterations in the photosynthetic pigments and antioxidant machineries of red pepper (Capsicum annuum L.) seedlings from gamma-irradiated seeds. Journal of Plant Biology, 47: 314-321.

Kim, J.; Chung, B.; Kim, J. \& Wi, S. (2005). Effects of in planta gamma-irradiation on growth, photosynthesis, and antioxidative capacity of red pepper (Capsicum annuum L.) plants. Journal of Plant Biology, 48(1): 47-56.

Kovács, E. \& Keresztes, A. (2002). Effect of gamma and UV-B/C radiation on plant cells. Micron, 33: 199-210.

Kumar, G. \& Singh, Y. (2010). Induced intergenomic chromosomal rearrangements in Sesamum indicum L. CYTOLOGIA, 75 (2):157-162.

Kumari, R. \& Singh, Y. (1996). Effect of gamma rays and EMS on seed germination and plant survival of Pisum sativum L., and Lens culinaris. Medical Neo Botanica, 4(1): 25-29.

Ladanova, N. (1993). The ultrastructural organization of pine needles after radiation exposure. Radiobiologia, (33(1):25-30.

Lambin, P.; Fertil, B.; Malaise, E. \& Joiner, M. (1994). Multiphasic survival curves for cells of human tumor cell lines: Induced repair or hypersensitive subpopulation? Radiation Research, 138:32-36.

Lanza, V.; Pretazzoli, V.; Olivieri, G.; Pascarella, G.; Panconesi, A. \& Negri, R. (2005). Transcriptional response of human umbilical vein endothelial cells to low doses of ionizing radiation. Journal of Radiation Research, 46:265-276.

Lemus, Y.; Méndez-Natera, J.; Cedeño, J. \& Otahola-Gómez, V. (2002). Radiosensibilidad de dos genotipos de frijol (Vigna unguiculata (L.) Walp. a radiaciones gamma. Revista UDO Agrícola, 2: 22-28.

Luckey, T. (1980). Hormesis with ionizing radiations. CRC press. Boca Raton, FLO, USA.

Luckey, T. (1991). Radiation Hormesis. CRC press. Boca Raton, FLO, USA.

Luckey, T. (1998). Radiation Hormesis: Biopositive effect of Radiation. Radiation Science and Health. CRC press. Boca Raton, FLO, USA.

Luckey, T. (2003). Radiation for health. Radio Protection Management, 20:13-21.

Maluszynski, M.; Ahloowalia, B. \& Sigurbjörnsoon, B. (1995). Application of in vitro and in vivo mutation techniques for crop improvent. Euphytica, 85:303-3-15.

Manzanilla, H. (1974). Investigaciones Epidométricas y Silvícolas en Bosques Mexicanos de Abies religiosa. Dirección General de Información y Relaciones Públicas de la SAG. México, D. F.

Matsumoto, H.; Takahashi, A. \& Ohinishi, T. (2004). Radiationinduced adaptive response and bystander effects. Biological Science Space, 18:247-254.

Mendez-Alvarez, S.; Leisinger, U. \& Eggen, R. (1999). Adaptive responses in Chlamydomonas reinhardtii. International Microbiology, 2:15-22. 
Mergen, F. \& Stairs, G. (1962). Low level chronic gamma irradiation of a Pitch Pine-Oak forest-its physiological and genetical effects on sexual reproduction. Radiation Botany, 2(3-4):205-206.

Nwachukwu, E.; Ene, L. \& Mbanaso, E. (1994). Radiation sensitivity of two ginger varieties (Zingiber officinale Rosc.) for gamma irradiation. In: Der Tropenlandwirt, Zeltschrift für Die Lndwirtschaft In Den Tropen and Suptropen. Jahrgang, S. 93-103. South Africa.

Olvera, E. \& West, S. (1985). Aspects of germination of Leucaena. Tropical Agricultural, 62(1):68-72.

Orbovic', V.; Cálovic', M.; Viloria, Z.; Nielsen, B.; Gmitter, F.; Castle, W. \& Grosser, J. (2008). Analysis of genetic variability in various tissue culture-derived lemon plant populations using RAPD and flow cytometry. Euphytica, 161:329-335.

Pajovic, S.; Joksic, G.; Pejic, S.; Kasapovic, J. \& Cuttone, L. (2001). Antioxidant dose response in human blood cells exposed to different types of irradiation. The Sciences, 1:133136.

Panda, K.; Patra, J. \& Panda, B. (1997). Persistence of cadmium- induced adaptive response to genotixicity of maleic hydrazide and methyl mercuric chloride in root meristem cells of Allium cepa L.: Differential inhibition by cycloheximide and buthionine sulfoximine. Mutation Research, 389:129-139.

Patra, J.; Sahoo, M. \& Panda, B. (2003). Persistence and prevention of aluminium- and paraquat-induced adaptive response to methyl mercuric chloride in plant cells in vivo. Mutation Research, 538:51-61.

Predieri, S. (2001). Mutation induction and tissue culture in improving fruits. Plant Cell, Tissue and Organ Culture, 64:185-210.

Raghava, R. \& Raghava, N. (1989). Effect of gamma irradiation on fresh and dry weight of plant parts in Physallis L. Geobios, 16(6): 261-264.

Ramírez, R.; González, L.; Camejo, Y.; Zaldivar, N. \& Fernández, Y. (2006) Estudio de radiosensibilidad y selección del rango de dosis estimulantes de rayos $X$ en cuatro variedades de tomate (Lycopersicon esculentum Mill). Cultivos Tropicales, 27(1):63-67.

Ramírez-Calderón, J.; Cervantes-Santana, T.; Villaseñor-Mir, H. \& López-Castañeda, C. (2003). Selección para componentes del rendimiento de grano en triticale irradidado. Agrociencia, 37(6): 595-603.

Rasheed, S.; Tahira, F.; Khurram, B.; Tayyab, H. \& Shiekh, R. (2003). Agronomical and physiochemical characterization of somaclonal variants in Indica basmati rice. Pakistan Journal of Biological Science, 6:844-848.

Rieger, R.; Michaelis, A.; Jovtchev, G. \& Nicolova, T. (1993). Copper sulphate and lead nitrate pretreatments trigger "adaptive responses" to the induction of chromatid aberrations by maleic hydrazide (MH) and /or JEM in Vicia faba, Hordeum vulgare, and human peripheral blood lymphocytes. Biology Zentralbl, 112:18-27.

Rohankhedkar, M.; Mulrooney, S.; Wedemeyer, W. \& Hausinger, R. (2006). The AidB component of the Escherichia coli adaptive response to alkylating agents is a flavincontaining, DNA-binding protein. Journal of Bacteriology, 188:223-230. 
Rubinelli, P.; Siripornadulsil, S.; Gao-Rubinelli, F. \& Sayre, R. (2002). Cadmium- and ironstress-inducible gene expression in the green alga Chlamydomonas reinhardtii: Evidence for $H 43$ protein function in iron assimilation. Planta, 215:1-13.

Rudolph, T. (1979). Effects of gamma irradiation of Pinus banksiana Lamb. seed as expressed by M 1 trees over 10-year period. Environmental and Experimental Botany, 19(2):8592.

Sánchez-Velásquez, L. ; Pineda-López, M. \& Martínez-Hernández, A. (1991). Distribución y estructura de la población de Abies religiosa Schl. et Cham., en el Cofre de Perote, Estado de Veracruz, México. Acta Botánica Mexicana, 16: 45-55.

Sánchez-Velásquez, L. \& Pineda-López, M. (1993). Conservación y desarrollo rural en zonas de montaña: El manejo forestal como un elemento potencial en Veracruz. BIOTAM, 5:35-44.

Sangwan, H. \& Singh, R. (1977). Pattern of gamma ray-induced polygenic variability in mung (Vigna radiata (L) Wilcrek). Journal of Genetics, 63(2):83-88.

Savina, N.; Dalivelya, O. \& Kuzhir, T. (2003). Adaptive response to alkylating agents in the Drosophila sex-linked recessive lethal assay. Mutation Research, 535:195-204.

Schlade-Bartusiak, K.; Stembalska-Kozlowska, A.; Bernady, M.; Kudyba, M. \& Sasiadek, M. (2002). Analysis of adaptive response to bleomycin and mitomycin C. Mutation Research, 513:75-81.

Scott, B. \& Di Palma, J. (2006). Sparsely ionizing diagnostic and natural background radiations arelikely preventing cancer and other genomic-instability-associated diseases. Dose-Response, 5:230-255.

Singh, N. K. \& Balyan H. S. (2009) Induced mutations in bread wheat (Triticum aestivum L.) CV. "Kharchia 65 " for reduced plant height and improve grain quality traits. Advances in Biological Research, 3(5-6):215-221.

Shu, Q. \& Lagoda, P. (2007) Mutation techniques for gene discovery and crop improvement. Molecular Plant Breeding, 5:193-195.

Scott, R. B., Belinsky, S. A., Leng, S., Lin, Y., Wilder, J. A., Damiani, L. A. (2009) Radiationstimulated epigenetic reprogramming of adaptative-response genes in the lung: an evolutionary gift for mounting adaptative protection against lung cancer. DoseResponse, 7:104-131.

Scott, B. (2005). Stochastic thresholds: A novel explanation of nonlinear dose-response relationships. Dose-Response, 3:547-567.

Scott, B.; Belinsky, S.; Leng, S.; Lin, Y.; Wilder, J. \& Damiani, L. (2009). Radiationstimulated epigenetic reprogramming of adaptive-response genes in the lung: an evolutionary gift for mounting adaptive protection against lung cancer. DoseResponse, 7:104-131.

Sedgwick, B. \& Lindahl, T. (2002). Recent progress on the Ada response for inducible repair of DNA alkylation damage. Oncogene, 21:8886-8894.

Seo, H.; Chung, H.; Lee, Y.; Bae, S.; Lee, S. \& Lee, Y. (2006). p27Cip/Kip is involved in Hsp25 or inducible Hsp70 mediated adaptive response by low dose radiation. Journal of Radiation Research, 47:83-90.

Shu, Q. \& Lagoda, P. (2007). Mutation techniques for gene discovery and crop improvement. Molecular Plant Breeding, 5:193-195. 
Singh, N. \& Balyan, H. (2009). Induced mutations in bread wheat (Triticum aestivum L.) CV. "Kharchia 65" for reduced plant height and improve grain quality traits. Advances in Biological Research, 3(5-6), 215-221.

Sokolov, M.; Isayenkov, S. \& Sorochynskyi, B. (1998). Low-dose irradiation can modify viability characteritics of common pine (Pinus sylvestris) seeds. Tsitologiya Genetika, 32(4): 65- 71.

Solís P. (1994). Monografía de Pinus hartwegii Lindl. Tesis de licenciatura. División de Ciencias Forestales, Universidad Autónoma Chapingo. Chapingo, México.

Sparrow, A. \& Woodwell, G. (1962). Prediction of the sensitivity of plants to chronic gamma irradiation. Radiation Botany, 2(1): 9-12.

Thapa, C. (1999). Effect of acute exposure of gamma rays on seed germination of Pinus kesiya Gord and P. wallichiana A.B. Jacks. Botanica Orientalis Journal of Plant Science, 120121.

Tiku, A. \& Kale, R. (2001). Radiomodification of glyoxalase I in the liver and spleen of mice: Adaptive response and split-dose effect. Molecular Cell Biochemistry, 216:79-83.

Ulsh, B.; Miller, S.; Mallory, F.; Mitchel, R.; Morrison, D. \& Boreham, D. (2004). Cytogenetic dose-response and adaptive response in cells of ungulate species exposed to ionizing radiation. Journal of Environment Radioactive, 74:73-81.

Vaiserman, A. (2010). Hormesis, adaptive epigenetic reorganization, and implications for human health and longevity. Dose Response, 8(1):16-21.

Vasilevski, G. (2003). Perspectives of the application of biophysical methods in sustainable agriculture. Bulgarian Journal of Plant Physiology, Special Issue:179-186.

Wang, G. \& Cai, L. (2000). Induction of cell proliferation hormesis and cell-survival adaptive response in mouse hematopoietic cells by whole-body low-dose radiation. Toxicology Science, 53:369-376.

Ward, J. (1988). DNA damage produced by ionizingradiation in mammalian cells: identities, mechanisms of formation, and repairability. Programing Nucleic Acid Research and Molecular Biology. 35: 96-128.

Wi, S.; Chung, B.; Kim, J.; Baek, M.; Yang, D.; Lee J. \& Kim, J. (2005).Ultrastructural changes of cell organelles in Arabidopsis stem after gamma irradiation. Journal of Plant Biology, 48(2): 195-200.

Williams, C. \& Savolaienen, O. (1996). Inbreeding Depression in Conifers: Implications for Breeding Strategy. Foretry Science, 42: 102-117.

Wolff, S. (1998). The adaptive response in radiobiology: evolving insights and implications. Environ Health Perspective, 106(1):277-283.

Yamaguchi, H.; Shimizu, A.; Degi, K. \& Morishita T. (2008). Effect of dose and dose rate of gamma ray irradiation on mutation induction and nuclear DNA content in chrysanthemum. Breeding Science, 58:331-335.

Yan, G.; Hua, Z.; Du, G. \& Chen, J. (2006). Adaptive response of Bacillus sp. F26 to hydrogen peroxide and menadione. Current Microbiology, 52:238-242.

Zaka, R.; Chenal, C. \& Misset, M. (2004). Effects of low doses of short-term gamma irradiation on growth all development through two generations of Pisum sativum. Science Total Environment, 320:121-129. 
Zhou, H.; Randers-Pehrson, G.; Waldren, C. \& Hei, T. (2004). Radiation- induced bystander effect and adaptive response in mammalian cells. Advance Space Research, 34:13681372. 


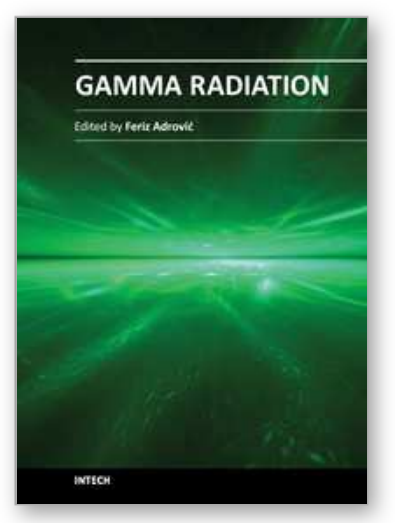

\author{
Gamma Radiation \\ Edited by Prof. Feriz Adrovic
}

ISBN 978-953-51-0316-5

Hard cover, 320 pages

Publisher InTech

Published online 21, March, 2012

Published in print edition March, 2012

This book brings new research insights on the properties and behavior of gamma radiation, studies from a wide range of options of gamma radiation applications in Nuclear Physics, industrial processes, Environmental Science, Radiation Biology, Radiation Chemistry, Agriculture and Forestry, sterilization, food industry, as well as the review of both advantages and problems that are present in these applications. The book is primarily intended for scientific workers who have contacts with gamma radiation, such as staff working in nuclear power plants, manufacturing industries and civil engineers, medical equipment manufacturers, oncologists, radiation therapists, dental professionals, universities and the military, as well as those who intend to enter the world of applications and problems of gamma radiation. Because of the global importance of gamma radiation, the content of this book will be interesting for the wider audience as well.

\title{
How to reference
}

In order to correctly reference this scholarly work, feel free to copy and paste the following:

L. G. Iglesias-Andreu, P. Octavio-Aguilar and J. Bello-Bello (2012). Current Importance and Potential Use of Low Doses of Gamma Radiation in Forest Species, Gamma Radiation, Prof. Feriz Adrovic (Ed.), ISBN: 978953-51-0316-5, InTech, Available from: http://www.intechopen.com/books/gamma-radiation/currentimportance-and-potential-use-of-low-doses-of-gamma-radiation-in-forest-species

\section{INTECH}

open science | open minds

\author{
InTech Europe \\ University Campus STeP Ri \\ Slavka Krautzeka 83/A \\ 51000 Rijeka, Croatia \\ Phone: +385 (51) 770447 \\ Fax: +385 (51) 686166 \\ www.intechopen.com
}

\author{
InTech China \\ Unit 405, Office Block, Hotel Equatorial Shanghai \\ No.65, Yan An Road (West), Shanghai, 200040, China \\ 中国上海市延安西路65号上海国际贵都大饭店办公楼405单元 \\ Phone: +86-21-62489820 \\ Fax: $+86-21-62489821$
}


(C) 2012 The Author(s). Licensee IntechOpen. This is an open access article distributed under the terms of the Creative Commons Attribution 3.0 License, which permits unrestricted use, distribution, and reproduction in any medium, provided the original work is properly cited. 